\title{
Endo- i egzogeniczne przyczyny marginalizacji Stronnictwa Demokratycznego w latach 90. XX wieku
}

\begin{abstract}
Streszczenie: Przedmiotem badań jest Stronnictwo Demokratyczne, które powstało jeszcze w okresie II Rzeczypospolitej Polskiej. Po II wojnie światowej było jednym z elementów polskiego systemu partyjnego. Celem opracowania jest prezentacja wewnętrznych i zewnętrznych czynników, które miały wpływ na marginalizację polityczną SD w latach 90 . XX wieku. Zebrano w jedną całość i uzupełniono rozproszone w różnych opracowaniach autora uwagi dotyczące tytułowej problematyki oraz dokonano ponownej interpretacji. Kryzys przywództwa w partii, brak konsekwencji w podejmowanych działaniach, likwidacja zasobów prasowych, konflikty w relacjach kierownictwa SD z instancjami terenowymi, odpływ członków, rozpad komitetów i kół, słaba znajomość zasad demokracji, niezdolność do przygotowania atrakcyjnej oferty programowej, częste zmiany partyjnych liderów - to najważniejsze przyczyny wewnętrzne, które przesądziły o marginalizacji politycznej SD. Istotne były tu też względy zewnętrzne. Przede wszystkim funkcjonowanie w warunkach systemu partii hegemonicznej nie sprzyjało rozwojowi organizacyjnemu, kadrowemu i programowemu, co musiało powodować różne deformacje. Po 1989 roku, w warunkach swobodnego kształtowania się systemu partyjnego, nowe ugrupowania oskarżały SD o współpracę z PZPR i legitymizowanie systemu politycznego PRL; pamiętali też o tym wyborcy. Wszystkie podejmowane w takich warunkach przez tę partię działania polityczne kończyły się porażką i potęgowały wewnętrzny kryzys.
\end{abstract}

Słowa kluczowe: Stronnictwo Demokratyczne, lata 90. XX wieku, marginalizacja polityczna, przyczyny wewnętrzne, przyczyny zewnętrzne

\section{Wprowadzenie}

- tronnictwo Demokratyczne (SD) powstało przed wybuchem II wojny światowej. - Rodowód ideowy rodzącego się wówczas ruchu politycznego związany był z tradycją polskich dążeń wolnościowych oraz nurtem demokratycznym w polskiej myśli politycznej XIX i początków XX wieku. Był też wypadkową nastrojów i postaw ujawniających się w środowiskach polskiej inteligencji w drugiej połowie dwudziestolecia międzywojennego oraz reakcją na styl sprawowania władzy przez sanację. Najpierw, od 1937 roku, rozwijały działalność kluby demokratyczne, a następnie zaczęto tworzyć bardziej zwarte, partyjne struktury organizacyjne. Efektem tak postępującego procesu było powołanie do życia w połowie kwietnia 1939 roku Stronnictwa Demokratycznego (Stronnictwo Demokratyczne w latach, 1967, s. 19).

W pierwszych partyjnych dokumentach programowych silnie podkreślano, że sprawowanie władzy publicznej w Polsce powinno wynikać z zastosowania „w pełni demokratycznego prawa wyborczego". Akcentowano szczególną rolę w państwie Sejmu i samorządu terytorialnego, uznając te instytucje za najwłaściwsze formy udziału obywateli 
w rządzeniu. Przestrzegano przed groźbą zaborczości ze strony sąsiedzkich państw totalitarnych, Związku Radzieckiego i Niemiec. Za podstawę polskiej polityki zagranicznej uznawano sojusz z Francją oraz zbliżenie z Wielką Brytanią i Stanami Zjednoczonymi Ameryki. Jednocześnie zacieśniać należało stosunki polityczne i gospodarcze z narodami czeskim, słowackim i litewskim, co sprzyjać miało budowaniu autorytetu Polski, jako siły reprezentującej interesy Europy Centralnej (Deklaracja, 1964, s. 515-525).

W czasie wojny SD prowadziło działalność konspiracyjną pod kryptonimem „Prostokąt” i pozostawało pod wpływem obozu londyńskiego. Członkowie SD „Prostokąt” przez cały czas okupacji uczestniczyli w zbrojnych organizacjach Polski Walczącej. Byli obecni we władzach wojskowych Związku Walki Zbrojnej, a następnie Armii Krajowej (Wosiński, 1980, s. 36).

Po II wojnie światowej Polska - za przyzwoleniem mocarstw zachodnich - znalazła się w strefie wpływów Związku Radzieckiego. W ten sposób pozbawiono ją prawa do niepodległego bytu, a kształt jej systemu politycznego został przesądzony jako niedemokratyczny. SD pozostało na scenie politycznej, ale kosztem ustępstw i utraty swego pierwotnego charakteru. Uwidoczniły się dwa wewnętrzne nurty - zmierzający do podporządkowania SD partii komunistycznej i preferujący samodzielność w działaniu - które ścierały się ze sobą z różnym natężeniem w całym okresie Polski Ludowej.

W październiku 1948 roku SD musiało określić stosunek do budowanego ustroju i postanowiło „towarzyszyć masom pracującym w tym marszu ku socjalizmowi” (Stronnictwo Demokratyczne w Polsce Ludowej, cz. I, 1968, s. 274). Wówczas takie deklaracje składało nie tylko SD. Dziesięć lat później - w 1958 roku - SD zaznaczyło, że jest partią niemarksistowską i wystąpiło z propozycją modyfikacji ustroju, akcentując jednocześnie konieczność włączenia w procesy demokratyzacji inteligencji technicznej i humanistycznej. Twierdzono, że ta grupa ludzi spełnia funkcje nieodzowne w tworzeniu nowych wartości (Stronnictwo Demokratyczne w Polsce Ludowej, cz. II, 1970, s. 408). Warto zauważyć, że tego typu poglądy - o kluczowej roli inteligencji w procesie rozwoju społeczeństwa i państwa - podważały istotę i rolę sojuszu robotniczo-chłopskiego i deformowały podstawy ówczesnego ustroju. $Z$ tych powodów wzbudziły dezaprobatę w Polskiej Zjednoczonej Partii Robotniczej (PZPR) i szybko zostały przez tę partię zastopowane. Podobnie było z „Wytycznymi Programowymi SD” z przełomu lat 1964/1965, w których SD dodatkowo podkreśliło znaczenie własności prywatnej i praworządności w państwie (Wrona, 1990, s. 92-93).

Poszukiwanie nowych koncepcji i rozwiązań programowych ponownie podjęto na przełomie lat 70. i 80. XX wieku w warunkach ostrej niewydolności ustroju Polskiej Rzeczypospolitej Ludowej (PRL). Toczone wówczas w całym SD dyskusje niosły konstruktywną myśl i dały początek autonomicznemu programowi politycznemu tej partii, który ostatecznie uchwalony został podczas XII Kongresu w marcu 1981 roku (zob. Dokumenty, 1981). Zgłoszona wówczas przez SD reforma państwa miała dokonywać się w ramach istniejącego systemu politycznego. Zwraca jednak uwagę, że propozycja dotyczyła nie tylko spraw politycznych i społecznych, ale także i gospodarczych. Był to program odmienny od dotychczas realizowanych w Polsce Ludowej. W obszarze politycznym przedstawiono koncepcję systemu parlamentarno-gabinetowego, w sferze ekonomicznej zaproponowano system z elementami gospodarki rynkowej. Praktyczne wzmocnienie pozycji ustrojowej Sejmu, który uznawano za najwyższy organ władzy, wiązano z jego demokratycznym wy- 
borem. Do systemu politycznego PRL proponowano wprowadzić instytucje, które będą strzegły praworządności - Trybunał Konstytucyjny i Trybunał Stanu. Gwarantem stabilności państwa miał zaś być prezydent, sytuowany przez demokratów ponad partiami politycznymi. Miały być zagwarantowane prawa i wolności człowieka i obywatela. Należało uznać Niezależny Samorządny Związek Zawodowy „Solidarność”, docenić działania Kościoła katolickiego oraz podnieść rolę samorządu terytorialnego. W gospodarce proponowano głębokie zmiany strukturalne, korzystne dla małych i średnich firm oraz preferujące indywidualną przedsiębiorczość. Dużo uwagi w przyjętym programie politycznym poświęcono inteligencji, nauce, kulturze, oświacie, ochronie środowiska, ochronie zdrowia, sportowi i turystyce - proponując zarazem kierunki konstruktywnych działań w obrębie każdej z tych kwestii społecznych. Proponowano też określenie minimum socjalnego, które powinno być systematycznie aktualizowane. Projektowane przemiany należało odzwierciedlić w konstytucji (Żebrowski, 2003, s. 74-91). Ówczesne wizje demokratów były przede wszystkim wynikiem oddolnych nacisków członków i znalazły, w znacznej mierze, odzwierciedlenie podczas obrad Okrągłego Stołu.

Celem artykułu jest prezentacja wewnętrznych i zewnętrznych czynników, które miały wplyw na marginalizację polityczną SD w latach 90 . XX wieku. Zakłada się, że niekorzystne tendencje w SD narastały i obie grupy przyczyn spowodowały upadek partii. Problem jest istotny, tym bardziej, że w ostatnich latach PRL SD wykazywało znaczną aktywność polityczną. W trakcie badań posłużono się metodą historyczną, systemową i behawioralną oraz techniką badania dokumentów i obserwacji. W przeprowadzonej analizie wykorzystano i uzupelniono rozproszone w różnych opracowaniach autora uwagi dotyczące tytułowej problematyki oraz ponownie dokonano interpretacji z dzisiejszej perspektywy.

W ostatnich latach PRL, a szczególnie w 1989 roku SD wykazywało znaczną aktywność polityczną. Miało samodzielny program, było widoczne przy Okrągłym Stole, wydatnie przyczyniło się do powstania rządu Tadeusza Mazowieckiego. SD reprezentowane było we wszystkich sektorach władz państwowych. Opracowało własny projekt konstytucji, który odzwierciedlał demokratyczną organizację państwa i parlamentarno-gabinetowy system rządów. Liderzy SD mogli liczyć na ponad 100 tys. członków, wśród których najliczniej reprezentowana była inteligencja i drobny biznes. SD miało struktury organizacyjne we wszystkich województwach, co stwarzało możliwość efektywnego realizowania podstawowych funkcji partii politycznych. Mogło wydawać się, że SD znalazło się w komfortowej sytuacji, w lepszej niż PZPR i Zjednoczone Stronnictwo Ludowe (ZSL); że w przyszłości, w III Rzeczypospolitej Polskiej (RP), odegra znaczną rolę i będzie istotnym elementem systemu partyjnego. Jednak tak się nie stało. SD w latach 90. XX wieku systematycznie traciło impet i uległo marginalizacji politycznej. Stan ten został wywołany zarówno przez czynniki wewnętrzne, jak i zewnętrzne.

\section{Przyczyny wewnętrzne}

Grupa przyczyn tkwiących wewnątrz tego Stronnictwa wiąże się najbardziej z postawami jego elit, a w szczególności partyjnych liderów, oraz członków. O ile konformizm przywódców SD i różne trudności wewnątrzpartyjne przed 1989 rokiem można było 
usprawiedliwiać wymogami realizowanego systemu i winą obciążać PZPR, to w III RP ten wygodny argument przestał istnieć. Od 28 lutego 1990 roku, kiedy do dymisji podał się Jerzy Jóźwiak, do końca analizowanej dekady SD kierowało pięciu przewodniczą$\mathrm{cych}^{1}$. Trzej pierwsi - Aleksander Mackiewicz, Zbigniew Adamczyk i Rafał Szymański - dopuścili w latach 1990-1993 do likwidacji bazy prasowej SD². Wraz z tymi działaniami kończyła się część tradycji SD, utrudniony też został kontakt z członkami i sympatykami. Zapoczątkowano też wyprzedaż znacznego majątku tej partii.

Już wolne wybory do rad gmin, które odbyły się 27 maja 1990 roku, ukazały realne możliwości polityczne SD. Mimo optymizmu przewodniczącego Centralnego Komitetu SD, A. Mackiewicza, dla którego dobry wynik w tych wyborach był oczywisty (Wybory, 1990, s. 3), SD w skali kraju zdołało obsadzić jedynie 1,66\% miejsc (864 mandaty) w radach gmin (Stronnictwo Demokratyczne w wyborach, 1990, s. 7). To poważne ostrzeżenie od elektoratu władze SD bagatelizowały, z porażki nie wyciągnięto żadnych wniosków, starano się natomiast w osiągniętym wyniku dostrzec elementy pozytywne. Wskazywano np., że reprezentacja Stronnictwa w radach, choć niewielka, to „stanowi poważny potencjał intelektualny o dużym zasobie wiedzy fachowej" (ibidem, s. 11).

Ponadto, podczas wyborów prezydenckich w 1990 roku lider SD był sprawcą wewnątrzpartyjnego konfliktu. Wbrew opiniom członków, którzy twierdzili, że są w stanie zebrać 100 tys. podpisów i zarejestrować kandydata, A. Mackiewicz i jego najbliższe otoczenie przeforsowali uchwałę o poparciu Lecha Wałęsy. Członkowie niezadowoleni z przyjęcia takiego kierunku ocenili, że SD nie odegra już samodzielnej roli i opuszczali szeregi partii.

W pierwszych wolnych wyborach do parlamentu, które odbyły się w 1991 roku, SD zanotowało kolejne niepowodzenie, zdobyło tylko jeden mandat w Sejmie. Listę nr 8 poparło wówczas 159017 uprawnionych obywateli, tj. 1,42\% (Stronnictwo Demokratyczne. Analiza, 1993, s. 3-6). W wyborach do Senatu kandydaci SD nie byli w stanie skutecznie włączyć się do rywalizacji o mandaty. Przewodniczącemu SD zarzucano słabą znajomość mechanizmów demokracji, amatorstwo i prowadzenie kampanii „w starym stylu". Wybory parlamentarne z 1991 roku potwierdzily, że SD było partią nieprzygotowaną do demokratycznej rywalizacji politycznej, niewiarygodną w oczach wyborców i pogłębiły procesy jej wewnętrznego rozkładu. Przedstawiciele tego Stronnictwa zostali W większości usunięci ze stanowisk w ministerstwach; tym samym udział w procesie decyzyjnym i jakikolwiek wpływ na sprawy państwa stał się niemożliwy.

Narastająca krytyka doprowadziła do zmiany na stanowisku przewodniczącego. Od 14 grudnia 1991 roku Stronnictwem kierował Z. Adamczyk. Nowy lider, zupełnie nieznany w kręgach politycznych i pozbawiony cech przywódczych, nie mógł odwrócić negatywnych tendencji, jak również nawiązać skutecznego dialogu politycznego. W czasie

${ }^{1}$ Dwie osoby przez krótkie okresy pełniły obowiązki przewodniczącego. Wiesław Kowalczuk po odwołaniu z funkcji przewodniczącego Rafała Szymańskiego i Marek Wieczorek po śmierci przewodniczącego Jana Janowskiego.

2 W dniu 9 września 1990 roku ukazał się ostatni numer „Tygodnika Demokratycznego” („Tygodnik Demokratyczny” 1990, nr 36). Sprzedano poczytne dzienniki „Kurier Polski” i „Ilustrowany Kurier Polski”. Zrezygnowano z wydawania „Zeszytów Historyczno-Politycznych”, które były miejscem wymiany naukowych poglądów. 
półrocznego przewodniczenia zdążył jednak sfinalizować transakcję o sprzedaży „Kuriera Polskiego" Zygmuntowi Solorzowi.

Następcą Z. Adamczyka był R. Szymański, który deklarował uczynienie z SD partii nowoczesnej, zdolnej do wygrywania wyborów oraz zapowiadał nowy program gospodarczy dla Polski i „marsz do władzy” (Ławrynowicz, 1993). Nowy przewodniczący nie miał wątpliwości, że przyszłość będzie należała do jego partii. Pytany jednak przez członków o zapowiadany program gospodarczy odpowiadał enigmatycznie: ,jest - na razie - objęty tajemnicą, aby nie został przechwycony przez inne ugrupowania polityczne" (Cienie, 1993). W rzeczywistości żadnego oryginalnego programu nie było. R. Szymański niechętnie zwoływał posiedzenia organów statutowych i w środowisku szybko zyskał przydomek ,wodza”. Niebawem okazało się, że forsuje on koncepcję „ograniczonego udziału SD w wyborach parlamentarnych w 1993 roku”. Zrezygnowano więc z wystawienia własnej partyjnej listy, członkowie SD - w liczbie 83 - kandydowali natomiast do Sejmu z różnych list (Rada, 1993). Sprawiło to, że nie mogli oni prezentować w trakcie kampanii poglądów swej partii. Wtopili się natomiast w nurt problematyki Sojuszu Lewicy Demokratycznej (SLD), Unii Pracy (UP), Polskiego Stronnictwa Ludowego (PSL), Bezpartyjnego Bloku Wspierania Reform (BBWR) i Unii Polityki Realnej (UPR).

Do izby pierwszej parlamentu wybranych zostało wówczas 3 członków SD. W kierownictwie spekulowano, że utworzą oni koło parlamentarne. Zamiast tego zbliżyli się do ugrupowań (SLD i UP), które zapewniły im mandaty. Żaden z 17 kandydatów tego Stronnictwa nie wszedł do izby drugiej parlamentu, batalię o mandat senatorski przegrał też lider SD. Porażka wpłynęła na wzrost determinacji oddziałów terenowych, także bliskich dotąd współpracowników przewodniczącego. Do tego doszły jeszcze zarzuty o niegospodarność i wyłudzanie pożyczek bez uprawdopodobnionego zamiaru ich zwrotu. Brak oczekiwanych rezultatów politycznych i ogólne niezadowolenie członków doprowadziły do zawieszenia lidera SD przez Sąd Partyjny, a następnie wykluczenia go z SD.

Przejawy awanturnictwa w życiu wewnętrznym powodowały odpływ coraz liczniejszych grup działaczy. Opuszczała szeregi SD inteligencja, w tym pracownicy naukowi różnych dziedzin licznie dotąd w tej partii reprezentowani. Dlatego nie może dziwić nagła pustka programowa i brak kontynuacji samodzielnej myśli politycznej oraz logicznych odniesień do toczących się lawinowo w Polsce zjawisk. W tej sytuacji zagrożone i opuszczone przez SD poczuły się inne środowiska związane z tą partią - a więc rzemieślnicy, kupcy i przedstawiciele prywatnego transportu. W niedługim czasie - prawie w całości - opuścili oni szeregi SD, szukając wiarygodniejszych partnerów.

Trzej zaprezentowani liderzy SD najbardziej przyczynili się do upadku tej partii. Zarzucano im brak wiedzy politycznej i związaną z tym niespójność działań oraz łamanie wewnętrznego prawa (statutu), a więc swego rodzaju wzorca partyjnych zachowań. Słabo przygotowani do politycznego funkcjonowania w warunkach demokracji, nie potrafili uwolnić się od praktyk stosowanych w PRL. Kierowali się raczej własnymi wyobrażeniami, a stanowiska ekspertów, np. w przedmiocie wyborów, uznawali za subiektywne, bądź wręcz SD wrogie.

Kolejnym przewodniczącym SD był od 11 grudnia 1993 roku prof. Jan Janowski - naukowiec i jednocześnie jedyny w tym gronie doświadczony polityk. Przez pierwsze 
pół roku swej kadencji związany był sądowym sporem ze swym poprzednikiem, bo ten nie chciał się pogodzić z utratą stanowiska. J. Janowski podjął próbę odbudowy już znacznie osłabionego organizacyjnie SD, w którym pozostało 12200 członków (zob. Materiaty, 1998). Lansował przy tym pogląd odwołania się w programie politycznym do warstwy średniej. Kierowane przez niego SD zaczęło odnosić się do bieżących spraw kraju. Apelowano np. o szybkie uchwalenie konstytucji III RP, przyznanie Trybunałowi Konstytucyjnemu prawa do ostatecznego orzekania, ratyfikowanie konkordatu, wprowadzenie powiatów i dużych województw. Ciekawym elementem przyjętych 7 maja 1995 roku „Tez programowych SD” była forsowana przez lidera SD koncepcja systemu półprezydenckiego (Tezy, 1995, teza 36). Kierowane przez niego Stronnictwo jednoznacznie opowiadało się za przystąpieniem Polski do Unii Europejskiej i do Paktu Północnoatlantyckiego (Rada, 1995).

W celu zmobilizowania szeregów członkowskich i pokazania społeczeństwu, że SD istnieje lider tej partii podjął się kandydowania na urząd prezydenta w wyborach w 1995 roku. Jednak zebranie ustawowo wymaganych 100 tys. podpisów okazało się dla jego partii za trudne. Do 24 września 1995 roku, a więc na 4 dni przed końcowym terminem rejestracji kandydatów, w sztabie wyborczym SD zgromadzono ok. 81 tys. podpisów. Obradująca tego dnia Rada Naczelna SD postanowiła wycofać swego przedstawiciela z dalszego udziału w kampanii prezydenckiej (ibidem). Mimo to przewodniczący SD dążył do wyprowadzenia swej partii z izolacji politycznej. Wykorzystując układy polityczne z czasów rządu Tadeusza Mazowieckiego, podjął rozmowy z kierownictwem Unii Wolności (UW), które doprowadziły do zawarcia w dniu 8 lutego 1996 roku porozumienia programowego (Minimum, 1996). W jego ramach zorganizowano kilka wspólnych, nagłośnionych przez prasę konferencji (Wspólne założenia polityki edukacyjnej, 1996, s. 2; Wspólne założenia polityki rolnej, 1996, s. 1-2). Z UW zawarto też kontrakt na zbliżające się wybory parlamentarne. Przewidywał on, że w wyborach do Sejmu na liście krajowej UW znajdzie się w pierwszej piątce miejsce dla lidera SD oraz w trzeciej dziesiątce dwa miejsca dla innych członków tego Stronnictwa. Kandydaci SD mieli otwierać listy okręgowe UW w pięciu województwach. Zdaniem członków wynegocjowany układ nie stwarzał Stronnictwu szerszych możliwości i był przez nich krytykowany. Sytuację pogorszyła wiadomość o ciężkiej chorobie przewodniczącego $\mathrm{SD}^{3}$ i rezygnacji z kandydowania. Liderzy UW zareagowali zmianą kontraktu wyborczego i zaproponowali Stronnictwu dalsze miejsca (19 i 27), twierdząc, że 5 miejsce na ich liście krajowej było zarezerwowane personalnie dla J. Janowskiego.

SD w wyborach parlamentarnych w 1997 roku poniosło kolejną klęskę. Do Sejmu dostał się jedynie Jan Klimek z Katowic. Porażka przerodziła się w wewnętrzną frustrację i niezdolność do podejmowania skutecznych działań. Rozkład partii postępował, liczna grupa działaczy SD, tych którzy startowali w wyborach z list UW, została trwale przechwycona przez tę partię (Rada, 1997).

Po śmierci J. Janowskiego nasiliły się spory, bo doszła jeszcze kwestia obsady stanowiska przewodniczącego, i spowodowały, że SD nie było zdolne odnosić się do problemów istotnych dla kraju. Szeregowi członkowie przestali rozumieć swych działaczy i nastąpiła kolejna fala rezygnacji, wielu chciało nadal działać politycznie, ale w partiach

3 J. Janowski zmarł w Krakowie 3 kwietnia 1998 roku. 
mających wpływ na losy Polski. SD natomiast, w ich ocenie, stawało się czymś w rodzaju sekty, niezrozumiałej dla ogółu. W połowie 1998 roku do SD należało jedynie 5147 osób (zob. Materiaty, 1998).

Od 28 listopada 1998 roku do 8 czerwca 2002 roku na czele SD stał poseł J. Klimek. Słabo znał sytuację wewnętrzną w partii, którą przyszło mu poprowadzić, wynikało z tego wiele nieporozumień. Jego ambicją, podobnie jak poprzedników, był nowoczesny program i doprowadzenie do powrotu SD na scenę polityczną. Jego strategia miała polegać na podejmowaniu działań politycznych ,wyprzedzających czas w oparciu o dokładną prognozę wszystkich zdarzeń" (Rada, 1999). Jak się okazało były to tylko założenia i powstałe w związku z nimi złudzenia. W SD nie było już sił, które taki program mogłyby wypracować i wdrożyć. Rozpad bazy członkowskiej pogłębiły decyzje władz naczelnych SD o poparciu w wyborach prezydenckich w 2000 roku Aleksandra Kwaśniewskiego (Rada, 2000) i udziale w wyborach parlamentarnych w 2001 roku u boku SLD (Rada, 2001). „Zwrot w lewo” całkowicie zdezorientował nielicznych już członków. Odchodzący z SD twierdzili, że J. Klimek i jego współpracownicy zniweczyli kilkuletnie zabiegi odcinania się od tego nurtu politycznego.

Należy uznać, że w latach 90 . XX wieku deklaracje liderów SD o powrocie tej partii na scenę polityczną, o nowoczesnych programach, o zdolności wygrywania wyborów miały charakter emocjonalny, niekonsekwentny i niespójny. Dominowały postawy pozbawione szerszej refleksji intelektualnej. Często przeważały względy ambicjonalne, towarzyszyła temu zła analiza rzeczywistości i przecenianie realnych możliwości partii. Pozycja polityczna i organizacyjna SD ulegała ciągłemu osłabianiu, a sposób uprawiania polityki przez elity partyjne stał się jedną z przyczyn marginalizacji politycznej SD.

Można spotkać się z poglądem, iż partie polityczne o znacznym poziomie instytucjonalizacji są lepiej przystosowane do radzenia sobie z nowymi problemami i w efekcie proces ich adaptacji do nowej sytuacji jest łatwiejszy. W przypadku SD teza ta nie zyskała potwierdzenia. Rozbudowana struktura organizacyjna okazała się nieskuteczna w warunkach rozpoczętej demokratyzacji. Zrutynizowane zachowania części członków oraz konserwatywnie nastawionych etatowych pracowników pogłębiały niezdolność adoptowania się do nowej rzeczywistości politycznej. SD okazało się ,zbyt wolne”, kiedy decyzje polityczne trzeba było podejmować szybko. Gdy pojawiały się działania w kierunku przyjęcia nowych rozwiązań instytucjonalnych, idące w kierunku odbiurokratyzowania partii, następował opór wojewódzkich komitetów. Niektóre z nich, jak Kraków i Wrocław, przerodziły się w swoiste twierdze broniące istniejących tam zasobów, głównie materialnych. Pozwalano przy tym na rozpad miejskich komitetów i kół. Jednoczesne „odcięcie” SD od pieniędzy z budżetu państwa wprowadziło daleko idący chaos finansowy. Pośpiesznie wyprzedawano majątek, w tym - jak już zaznaczono - tytuły prasowe. Zamiast spodziewanej stabilizacji, następowała kumulacja trudności i destabilizacja.

\section{Przyczyny zewnętrzne}

Na wizerunek i możliwości polityczne SD w latach 90. XX wieku znaczny wpływ wywarły też czynniki zewnętrzne. Po II wojnie światowej dokonane pod presją partii robotniczych przewartościowania ideologii i programu (zob. Stronnictwo Demokratyczne 
w Polsce Ludowej, cz. I, 1968, s. 15-19) spowodowały niechęć społeczeństwa do SD. Podejmowane w PRL próby sformułowania samodzielnego programu politycznego powodowały zdecydowane reakcje PZPR i zaostrzenie kursu wobec SD.

SD podlegało stałej kontroli ze strony hegemonicznej PZPR, co wynikało ze specyfiki autorytaryzmu. Kontrola ta dotyczyła nie tylko warstwy programowej, także polityki kadrowej na wszystkich poziomach i rozwoju organizacyjnego. O niedopuszczenie do usamodzielnienia się SD bezpośrednio odpowiedzialni byli działacze, których nazywano „wtyczkami”. Skierowani przez PZPR do struktur organizacyjnych SD nadawali ton życiu partyjnemu. Jednocześnie tłumili przejawy i głosy tych członków i środowisk, które domagały się samodzielności partyjnej i demokratyzacji. Eliminowali osoby opowiadające się przeciw podporządkowaniu Stronnictwa innej partii. Metody te dotyczyły wszystkich szczebli organizacyjnych i nie stwarzały SD większych perspektyw politycznych. Decyzjom władz naczelnych SD, które takie praktyki akceptowały i stosowały, przeciwstawiały się niejednokrotnie całe instancje niższych szczebli, jak również szeregowi członkowie. Było to $\mathrm{z}$ czasem coraz trudniejsze $\mathrm{z}$ uwagi na scentralizowany aparat urzędniczy. Taka sytuacja doprowadziła do opanowania najważniejszych stanowisk we władzach SD przez działaczy komunistycznych i podważała w społeczeństwie autentyczność tego Stronnictwa.

SD podlegając stałej kontroli zarówno w obszarze organizacyjnym i kadrowym, jak też funkcjonalnym i programowym podatne było na różne deformacje. Jedynie w okresach kryzysów obserwowano większą samodzielność w tych zakresach. Ponadto brak w autorytaryzmie konkurencji i czynników mobilizujących przyzwyczaił członków SD do różnych sytuacji, w których temu Stronnictwu coś „z klucza” należało się (np. pewna liczba mandatów) i wpłynął na niezdolność do skutecznych działań w warunkach rywalizacji politycznej.

Po 1989 roku, kiedy następował w Polsce swobodny rozwój systemu partyjnego, SD znalazło się w nowym otoczeniu politycznym. W tych innych warunkach zewnętrznych liderzy tego ugrupowania liczyli na sukcesy polityczne. Oczywiste wydawały się im nowe możliwości współpracy (Polarczyk, 1989, s. 7), szczególnie po wejściu do koalicji z „Solidarnością" i utworzeniu rządu z niekomunistycznym premierem. Jednak rzeczywistość okazała się zupełnie inna. Nowopowstałe partie polityczne oskarżały SD o współpracę z PZPR i obciążały winą za niepowodzenia PRL, w tym za poparcie stanu wojennego (zob. Przed, 1989, s. 2-3). Podejmowane próby nawiązania relacji z tymi podmiotami kończyły się niepowodzeniem, często miały wymiar jedynie towarzyski. SD izolowane politycznie, nazywane partią postkomunistyczną traciło możliwość udziału w zachodzących procesach oraz wpływu na ich przebieg. Jednocześnie członkowie SD dostrzegli nowe możliwości aktywności partyjnej i partycypacji w życiu społeczno-politycznym. Nowa sytuacja zewnętrzna spowodowała, że opuszczali krytykowaną partię i zasilali szeregi innych, głównie Unii Demokratycznej (UD), Kongresu Liberalno-Demokratycznego (KLD) i Porozumienia Centrum (PC).

W SD wielokrotnie podejmowano kwestię rozliczenia się z przeszłością; sam przecież udział w koalicji z PZPR legitymizował istniejący wówczas system polityczny. Nigdy jednak nie uczyniono tego rzetelnie, zawsze dominowały bezkrytyczne samooceny. Natomiast opinie wychodzące z zewnątrz, od bezstronnych ekspertów, często krytyczne, uznawano za złośliwe, tendencyjne i były bagatelizowane. Eksperci sugerowali np., że szansę powrotu SD na scenę polityczną należy wiązać z budową nowoczesnego programu i konsekwentnym udziałem w wyborach pod własnym szyldem. Zaznaczano, że 
pozwoli to odzyskać stracony i pozyskać nowy elektorat oraz mobilizować wokół celów SD. Podkreślano, że działanie takie będzie trudne i liczyć się tu trzeba z kilkuletnim okresem odbudowy politycznych wpływów. Jedną z koncepcji odbudowy SD i zatarcia negatywnych skojarzeń mogła być zmiana nazwy partii. Zaznaczano, że nie musiałoby to oznaczać zerwania z całym dziedzictwem SD. Działanie to mogłoby być zamknięciem pewnego rozdziału historii i rozpoczęciem procesów związanych z tworzeniem nowego modelu partii. Jednocześnie eksperci sugerowali, biorąc pod uwagę dotychczasową myśl programową SD, że najkorzystniejsze byłoby umieszczenie ugrupowania w centrum przestrzeni rywalizacji politycznej. Dawałoby to dość dużą elastyczność i możliwość wyboru najbardziej korzystnych rozwiązań.

Zarówno w wariancie zakładającym żmudną odbudowę, jak i w przypadku zmiany nazwy dla polityków wdrażających te procesy zasadnicza powinna być kwestia, do kogo kierować ofertę programową; czy do określonej grupy społecznej, czy do całego społeczeństwa. SD najbardziej było przygotowane do ukierunkowania działalności na drobnych przedsiębiorców, rzemieślników i kupców. Chęć odwołania się w programie do całego społeczeństwa, co jest preferowane przez współczesne partie polityczne, wymagała dopasowania do tego struktur organizacyjnych, utworzenia wydziałów lub komisji, które zajmą się sprawami poszczególnych części elektoratu. Należało też skorzystać z usług osób, które profesjonalnie zadbają o wizerunek partii i jej liderów.

\section{Podsumowanie}

Skutki wywołane przez czynniki wewnętrzne i zewnętrzne kumulowały się i doprowadziły do marginalizacji politycznej SD. Wszystkie podejmowane w latach 90. XX wieku działania polityczne kończyły się porażką i potęgowały wewnętrzny kryzys. SD nie było w stanie zaoferować żadnej grupie społecznej jakichś wymiernych korzyści, a tym samym nie mogło liczyć na poparcie w wyborach. Ponadto wyborcy, jak też nowi aktorzy sceny politycznej uznali, że SD współdziałając z PZPR i ZSL legitymizowało autorytaryzm i ponosi odpowiedzialność za niepowodzenia PRL. SD coraz powszechniej postrzegane było jako partia postkomunistyczna, z którą współpraca jest niepożądana. Zachowania elit SD, w tym partyjnych przywódców nie mobilizowały członków do realizacji wspólnych celów w warunkach rywalizacji politycznej, nasilały natomiast destrukcję. Szczególnie dotkliwe okazało się wyjście z SD inteligencji, bez której zaprojektowanie i wdrożenie działań modernizacyjnych stało się niemożliwe. Destabilizację pogłębiało ignorowanie opinii zewnętrznych ekspertów o możliwości powrotu SD do udziału w życiu politycznym. SD - które formalnie jeszcze istnieje - nie odgrywa w systemie politycznym żadnej roli, nie realizuje żadnych funkcji; dla obywateli jest zjawiskiem nieznanym.

\section{Bibliografia}

Cienie SD, „Gazeta Współczesna” z dnia 8.03.1993 r.

Deklaracja Programowa Stronnictwa Demokratycznego (1964), w: Materiaty do historii Klubów Demokratycznych i Stronnictwa Demokratycznego w latach 1937-1939, cz. 1, Wydawnictwo Epoka, Warszawa. 
Dokumenty i materiały XII Kongresu Stronnictwa Demokratycznego (1981), Wydawnictwo Epoka, Warszawa.

Ławrynowicz J. (1993), Boso ale w ostrogach, „Kurier Szczeciński” z dnia 24.02.1993 r.

Materiaty informacyjno-sprawozdawcze na XIX Kongres Stronnictwa Demokratycznego (1998), Wydawnictwo RN SD, Warszawa.

Minimum Programowe (1996), „Kurier Kongresowy”, nr 2.

Polarczyk K. (1989), O porozumiewaniu się demokratów, „Tygodnik Demokratyczny”, nr 50.

Przed Ogólnopolskim Forum Demokratów (1989), „Tygodnik Demokratyczny”, nr 47.

Rada Naczelna Stronnictwa Demokratycznego (1993), Posiedzenia RN SD.

Rada Naczelna Stronnictwa Demokratycznego (1995), Posiedzenia RN SD.

Rada Naczelna Stronnictwa Demokratycznego (1996), Posiedzenia RN SD.

Rada Naczelna Stronnictwa Demokratycznego (1997), Posiedzenia RN SD.

Rada Naczelna Stronnictwa Demokratycznego (1999), Posiedzenia RN SD.

Rada Naczelna Stronnictwa Demokratycznego (2000), Posiedzenia RN SD.

Rada Naczelna Stronnictwa Demokratycznego (2001), XIX Kongres SD.

Rada Naczelna Stronnictwa Demokratycznego (2002), XX Kongres SD.

Stronnictwo Demokratyczne. Analiza wyborów do Sejmu Rzeczypospolitej Polskiej z 27.10.1991 r. (1993), Wydawnictwo RN SD, Warszawa.

Stronnictwo Demokratyczne w latach 1937-1965 (1967), Wydawnictwo Epoka, Warszawa.

Stronnictwo Demokratyczne w Polsce Ludowej, cz. I Wybór dokumentów z lat 1944-1949 (1968), Wydawnictwo Epoka, Warszawa.

Stronnictwo Demokratyczne w Polsce Ludowej, cz. II, t. 1: Wybór dokumentów z lat 1950-1958 (1970), Wydawnictwo Epoka, Warszawa.

Stronnictwo Demokratyczne w wyborach do samorządu terytorialnego w dniu 27 maja 1990 r. (1990), Wydawnictwo CK SD, Warszawa.

Tezy programowe Stronnictwa Demokratycznego (1995), Wydawnictwo RNSD, Warszawa.

Wosiński H. (1980), Stronnictwo Demokratyczne w latach II wojny światowej, Wydawnictwo Epoka, Warszawa.

Wrona J. (1990), Stronnictwo Demokratyczne w systemie politycznym PRL 1944-1965, „Zeszyty Historyczno-Polityczne Stronnictwa Demokratycznego", nr 3.

Wspólne założenia polityki edukacyjnej, „Biuletyn Stronnictwa Demokratycznego” z dnia 23.10.1996 r.

Wspólne założenia polityki rolnej ogłoszone na konferencji „,Nowoczesna wieś polska” (1996), „Kurier Kongresowy", nr 6.

Wybory to akt racjonalny (1990), „Tygodnik Demokratyczny”, nr 21.

Żebrowski W. (2003), Stronnictwo Demokratyczne w warunkach demokratyzacji ustroju politycznego, Wydawnictwo Olsztyńskiej Szkoły Wyższej, Olsztyn.

\section{Endo- and exogenous causes of marginalization of the Democratic Party in the 1990s}

\section{Summary}

The subject of research is the Democratic Party, which was established during the Second Polish Republic. After World War II, it was one of the elements of the Polish party system. The aim of the study is to present the internal and external factors that influenced the political marginalization of SD in the 1990s. Remarks on the subject of the title, which were scattered in various publications by the 
author, were collected and re-interpreted. The crisis of the leadership in the party, lack of consistency in the actions taken, liquidation of press resources, conflicts in the relations between the SD leadership and field instances, the outflow of members, disintegration of committees and circles, poor knowledge of democratic principles, inability to prepare an attractive program offer, frequent changes of party leaders - this is the most important internal causes that determined the political marginalization of the SD. External considerations were also important here. First of all, functioning in the conditions of the hegemonic party system was not conducive to organizational, personnel and program development, which had to cause various deformations. After 1989, in the conditions of the free formation of the party system, the new groups accused the SD of cooperation with the Polish United Workers' Party and legitimizing the political system of the People's Republic of Poland; voters also remembered it. All political activities undertaken by this party under such conditions ended in failure and exacerbated the internal crisis.

Key words: Democratic Party, the 90s of the 20th century, political marginalization, internal causes, external causes 
